\title{
AGROGSTA
}

Journal Agroista. Vol. 5 ,No.2 November 2021

Journal home page: https://jurnal.instiperjogja.ac.id/index.php/AGI

ISSN : $2597-3835$

e-ISSN : : $2684-7019$

\section{APLIKASI CENDAWAN ENTOMOMOPATOGEN Cordyceps militaris PADA HAMA ULAT API (Setothosea asigna) DI PERKEBUNAN SATYA KISMA USAHA UNIT BATANG GADING MUARA BUNGO JAMBI}

\section{APPLICATION OF ENTOMOPATHOGENIC FUNGI Cordyceps militaris ON INSECT PEST Setothosea asigna IN PLANTATION OF SATYA KISMA USAHA UNIT BATANG GADING MUARA BUNGO JAMBI}

\author{
Budi Purnama ${ }^{1}$, Achmad Himawan ${ }^{1}$, Samsuri Tarmadja ${ }^{1}$ \\ ${ }^{1}$ Department of Agrotechnology, Faculty of Agriculture, Stiper Agricultural Institute, \\ Yogyakarta, Indonesia \\ e-mail : wawanhimawan2014@gmail.com
}

\begin{abstract}
The aims of this research are to determine the best medium to propagation entomopathogenic fungi $C$. militaris, to determine effectivity and dosage of $C$. militaris to control pupae of $S$. asigna. This research was conducted in plantation of PT. Satya Kisma Usaha Unit Batang Gading, Tanah Tumbuh County, Muara Bungo District, Jambi. The research was conducted from August to September 2020. This study used a non-factorial method, which was arranged in a completely randomizing design (CRD) with 1 factor, namely growth media. The growth media are consisted of corn seeds (M1) and bran (M2) and repeated 5 times. For dosage of fungi used a non-factorial method, which was arranged in a CRD with 1 factor, namely bran media. The bran media dosages are $\mathrm{P} 0=$ control $(100 \mathrm{ml}$ aquadest $/$ polybag $), \mathrm{P} 1=10 \mathrm{~g} \mathrm{C}$. militaris $+100 \mathrm{ml}$ aquadest/polybag, $\mathrm{P} 2=20 \mathrm{~g} \mathrm{C}$. militaris $+100 \mathrm{ml}$ aquadest/polybag, P3 = $30 \mathrm{~g} \mathrm{C}$. militaris $+100 \mathrm{ml}$ aquadest/polybag $\mathrm{P} 4=40 \mathrm{~g} \mathrm{C}$. militaris $+100 \mathrm{ml}$ aquadest/polybag and all of them are repeated 4 times. The results showed that bran medium is the best medium for fungi propagation. C. militaris was effectively to control pupae of $S$. asigna. The best of fungi dosage is $\mathrm{P} 4=40 \mathrm{~g} \mathrm{C}$. militaris $+100 \mathrm{ml}$ aquadest/polybag. The highest pupae mortality $(100 \%)$ is achieved at 12 days observation.
\end{abstract}

Keywords: entomopathogenic fungi, Cordyceps militaris, bran, Setothosea asigna 


\section{PENDAHULUAN}

Kelapa sawit telah menjadi komoditas perkebunan yang berperan sangat penting dalam penerimaan devisa negara, penyerapan tenaga kerja, serta pengembangan perekonomian rakyat dan daerah. Perkebunan kelapa sawit di Indonesia mulai berkembang sejak tahun 80 an. Perkebunan kelapa sawit Indonesia saat ini sudah mencapai luas 16,381 juta hektare dan $41 \%$ dari total area adalah perkebunan rakyat (Dirjenbun, 2020)

Sejauh ini pemanfaatan kelapa sawit yang paling banyak adalah untuk Crude Palm Oil (CPO) dan Palm Kernel Oil (PKO). Namun belakangan kelapa sawit juga merambah dan mengarah ke biodiesel. Selain itu limbah kelapa sawit juga sudah dimanfaatkan untuk berbagai produk.

Dalam budidaya tanaman kelapa sawit ada beberapa kendala di antaranya adalah hama dan penyakit. Hama dan penyakit telah terbukti dapat menimbulkan kerusakan berat atau kematian bagi tanaman yang belum menghasilkan (TBM) dan tanaman menghasilkan (TM).

Salah satu hama yang paling banyak menyerang tanaman kelapa sawit adalah ulat api (Setothosea asigna). Stadia ulat api yang menganggu tanaman adalah di fase ulat (larva). Menurut Susanto dkk. (2005), ulat api merupakan jenis ulat pemakan daun kelapa sawit yang sering menimbulkan kerugian produksi hingga $70 \%$ di perkebunan kelapa sawit.

Untuk pengendalian pada fase larva memerlukan insektisida kimia dengan cara fogging, yang kalau dilakukan secara terus-menerus akan merugikan. Kerugian pemakaian insektisida kimia antara lain adalah matinya serangga atau hewan lain yang bukan sasaran. Selain itu biaya untuk pengendalian memakai insektisida kimia juga relatif besar. Alternatif lain pengendalian ulat api adalah pengendalian hayati pada fase pupa dengan jamur entomopatogen, yaitu Cordyceps militaris (Suziani, 2011). Pupa terletak di atas permukaan tanah dan tidak bergerak. Oleh karena itu pupa lebih mudah dikendalikan.

\section{Rumusan Masalah}

Usaha pengendalian ulat api (S. asigna) telah banyak dilakukan terutama pada fase larva baik pengendalian secara kimia maupun hayati. Pengendalian ulat api pada fase pupa belum banyak dilaporkan, baik secara kimia maupun hayati. Oleh karena itu perlu dilakukan penelitian pengendalian hayati dengan jamur entomopatogen C. millitaris. Tahap awal pengendalian hayati adalah bagaimana cara perbanyakan jamur C. militaris pada berbagai macam media. Langkah selanjutnya adalah bagaimana efektivitas jamur $\mathrm{C}$. militaris untuk mengendalikan fase pupa ulat api (S. asigna). 


\section{Tujuan Penelitian}

Penelitian dilaksanakan dengan tujuan untuk mengetahui macam media terbaik untuk perbanyakan jamur entomopatogen C. militaris, mengetahui efektivitas jamur entomopatogen C. millitaris untuk mengendalikan fase pupa ulat api (S. asigna) serta mengetahui dosis jamur entomopatogen $\mathrm{C}$. militaris yang paling efektif untuk mengendalikan fase pupa ulat api (S. asigna).

\section{METODOLOGI}

\section{Tempat dan Waktu Penelitian}

Penelitian dilaksanakan di kebun PT. Satya Kisma Usaha, Unit Batang Gading, Kecamatan Tanah Tumbuh, Kabupaten Muara Bungo, Provinsi Jambi. Penelitian dilaksanakan pada bulan Agustus-September 2020.

\section{Alat dan Bahan}

Alat yang digunakan dalam penelitian ini meliputi blender, sprayer, cangkul, gunting, timbangan analitik, gelas takar, saringan, lakban bening, kertas stempel, penggaris, panci kukusan, wadah berukuran $700 \mathrm{ml}$, alat tulis, dan kamera.

Bahan yang digunakan pada penelitian ini meliputi pupa ulat api (S. asigna) yang telah terinfeksi jamur C. militaris, pupa ulat api yang belum terinfeksi, dedak, jagung, alkohol $75 \%$, polybag ukuran $40 \times 40 \mathrm{~cm}$, tanah, aquades, dan air bersih.

\section{Metode Penelitian}

Untuk menentukan media yang terbaik pada perbanyakan jamur entomopatogen $\mathrm{C}$. militaris digunakan metode Rancangan Acak Lengkap (RAL) nonfaktorial dengan 2 perlakuan yaitu $\mathrm{M} 1$ = dedak dan $\mathrm{M} 2$ = jagung. Masing-masing perlakuan diulang 5 kali. Untuk menentukan dosis jamur entomopatogen C. militaris yang efektif untuk mengendalikan pupa ulat api digunakan metode Rancangan Acak Lengkap (RAL) nonfaktorial dengan 5 perlakuan yaitu $\mathrm{P0}=$ kontrol $(100 \mathrm{ml}$ air $/$ polybag $), \mathrm{P} 1=(10 \mathrm{~g} \mathrm{C}$. militaris $+100 \mathrm{ml}$ air $/$ polybag $), \mathrm{P} 2=(20$ g C. militaris $+100 \mathrm{ml}$ air /polybag $), P 3=(30 \mathrm{~g} \mathrm{C}$. militaris $+100 \mathrm{ml}$ air/polybag $), \mathrm{P} 4=(40 \mathrm{~g}$ C. militaris $+100 \mathrm{ml}$ air/polybag). Masing-masing perlakuan diulang sebanyak 4 kali sehingga diperoleh 20 unit percobaan.

\section{Pelaksanaan Penelitian}

Perbanyakan jamur entomopatogen C. millitaris. Pertama, mencari pupa ulat api S. asigna yang telah terinfeksi jamur C. millitaris. Persiapkan media dedak dan jagung untuk memperbanyak jamur C. millitaris. Dedak dan jagung secara sendiri-sendiri dicuci dan dikukus 
selama 30 menit kemudian didinginkan. Setelah dedak dan jagung dingin maka dimasukkan ke wadah plastik volume $700 \mathrm{ml}$. Menjelang media dedak dan jagung dingin, blender pupa yang terinfeksi jamur C. millitaris dengan 1 liter air. Setelah larutan tercampur homogen maka larutan disaring. Larutan disiramkan secara merata di atas permukaan media dedak dan jagung. Wadah plastik ditutup dan disimpan pada suhu ruang selama 5 hari.

Penyiapan media tempat meletakkan pupa S. asigna, peletakan pupa sehat dan aplikasi jamur entomopatogen C. militaris. Polybag yang telah disiapkan diisi dengan tanah yang berasal dari sekitar tanaman kelapa sawit. Pupa ulat api yang sehat diambil dari sekitar tanaman kelapa sawit. Pupa sebanyak 15 dimasukkan ke dalam polybag. Total ada 20 unit polybag.

Media yang berisi jamur C. militaris ditimbang sebanyak masing-masing perlakuan. Setelah itu dimasukkan ke dalam blender dan ditambah air bersih $100 \mathrm{ml}$ serta diblender hingga menjadi larutan homogen. Larutan disaring menggunakan saringan. Selanjutnya larutan dimasukkan ke dalam sprayer dan disemprotkan ke pupa sehat yang berada dalam polibag.

\section{Parameter Penelitian}

Dilakukan pengamatan tumbuhnya jamur pada hari ke-1 sampai ke-5 pada media perbanyakan jamur entomopatogen C. militaris.

Dilakukan pengamatan pupa yang terinfeksi dengan ciri-ciri yaitu munculnya hifa atau miselium $\mathrm{p}$ ad a pupa. Setelah itu dilakukan penghitungan persentase pupa terinfeksi dengan rumus:

$$
\begin{gathered}
P=\frac{a}{b} \times 100 \% \\
P=\text { Persentase pupa terinfeksi } \\
a=\text { jumlah pupa terinfeksi } \\
\mathrm{b}=\text { jumlah pupa yang diamati }
\end{gathered}
$$

Dilakukan pengamatan pada pupa yang mati terinfeksi dengan ciri-ciri yaitu tubuh pupa ditutupi oleh hifa jamur C. militaris, bila pupa digoyang maka akan terdengar bunyi, pupa menjadi keras (mumifikasi), pupa berubah warna dari coklat menjadi hitam. Setelah pupa yang mati diamati maka dipisahkan dari yang belum mati. Setelah itu dihitung persentase pupa yang mati terinfeksi dengan rumus: 


$$
P=\frac{a}{b} \times 100 \%
$$

$P=$ persentase pupa yang mati terinfeksi

$\mathrm{a}=$ jumlah pupa yang mati terinfeksi

$\mathrm{b}=$ jumlah pupa yang diamati

Analisis data yang digunakan yaitu sidik ragam dengan jenjang nyata $5 \%$, bila ada beda nyata antar perlakuan diuji lanjut menggunakan Duncan Multiple Range Test (DMRT) dengan jenjang nyata $5 \%$.

\section{HASIL DAN PEMBAHASAN}

Dari hasil pengamatan selama 5 hari terlihat bahwa perkembangan C. militaris pada media dedak lebih baik dibandingkan pada media jagung. Terlihat bahwa pada hari ke 3 miselium jamur mulai terbentuk pada semua media. Tetapi pada media dedak miselium sangat jelas terlihat, dan pada pengamatan di hari ke 5 media dedak sudah ditumbuhi miselium jamur dan terlihat juga bintik-bintik merah spora jamur mulai keluar. Hal ini karena nutrisi pada media dedak, yang berbentuk serbuk, lebih mudah diserap oleh jamur. Peristiwa ini sesuai dengan penelitian Rochman (2015) yang menyatakan dedak mengandung beberapa nutrisi yang diperlukan untuk perkembangan jamur. Nutrisi yang dibutuhkan dalam bentuk unsur hara seperti nitrogen, fosfor, belerang, karbon. Dedak mengandung protein, selulosa, serat, nitrogen, lemak, dan P2O5.

Pada media jagung pada hari ke 5 belum semuanya ditutupi oleh miselium jamur. Hal ini terjadi karena yang dipakai bukan jagung giling melainkan jagung utuh. Oleh karena itu nutrisinya sulit diserap oleh jamur.

Bila pupa mengalami infeksi jamur maka tampak pupa ditumbuhi miselium berwarna putih dan makin lama maka warna pupa berubah menjadi kehitaman. Persentase pupa yang terinfeksi disajikan pada tabel 1. Tabel 1 menunjukkan pupa terinfeksi mulai pada hari ke-6 dengan perlakuan P1 sampai dengan P4. Persentase tertinggi (39\%) terdapat pada perlakuan $\mathrm{P} 4$ dan terendah $(16,39 \%)$ pada perlakuan $\mathrm{P} 1$. Pada hari ke-12 persentase pupa S. asigna yang terinfeksi paling tinggi (100\%) terlihat pada perlakuan P4. Sebaliknya infeksi terendah (55\%) terlihat pada perlakuan $\mathrm{P} 1$. 
Tabel 1. Persentase pupa yang terinfeksi

\begin{tabular}{ccccc}
\hline Perlakuan & \multicolumn{4}{c}{ Waktu pengamatan (hari setelah aplikasi) } \\
& 3 & 6 & 9 & 12 \\
\cline { 2 - 5 } P0 & 0 & 0 & 0 & 0 \\
P1 & 0 & 16,39 & 33,34 & 55,00 \\
P2 & 0 & 20,00 & 48,34 & 71,67 \\
P3 & 0 & 23,35 & 51,67 & 76,69 \\
P4 & 0 & 39,00 & 70,00 & 100,00 \\
\hline
\end{tabular}

Mekanisme infeksi jamur C. militaris menurut Schgal \& Sagar (2006) yaitu askospora yang berada pada integumen larva maupun pupa melakukan penetrasi melalui pembuluh, dan mempunyai kemampuan untuk menghidrolisa lapisan kitin dari larva maupun pupa. Setelah jamur menginfeksi muncul hifa berbentuk silindris pada haemocoel pupa, kemudian hifa membentuk miselium dan menyebar pada seluruh tubuh pupa.

C. militaris dapat menyerang larva instar akhir maupun pupa (kepompong). Kepompong yang terinfeksi menjadi keras (mumifikasi), berwarna hitam, miselium membalut tubuh kepompong di dalam kokon. Miselium berkembang keluar dari dinding kokon dan terjadi diferensiasi membentuk rizomorf dengan beberapa cabang, berwarna merah muda. Ujung ujung rizomorf berdiferensiasi membentuk badan buah berisi peristesia dengan askus dan askopora. Infeksi pertama terjadi pada saat larva tua akan berkepompong, tetapi lebih banyak pada fase kepompong. Pada kondisi di lapangan, $C$. militaris tumbuh baik pada tempat tempat lembab di sekitar piringan kelapa sawit dan gawangan. Menurut hasil penelitian kepompong terinfeksi cukup tinggi dan bervariasi tergantung pada kondisi lingkungan dan media terutama kelembaban (Purba et al., 1989).

Infeksi pada pupa terjadi dalam jangka waktu yang berbeda. Infeksi dimulai pada hari ke 6 setelah aplikasi jamur $C$. militaris pada semua perlakuan. Infeksi tercepat terjadi pada perlakuan P3 dan P4 dengan dosis $30 \mathrm{~g}$ jamur C. militaris $+100 \mathrm{ml}$ air/polybag dan $40 \mathrm{~g}$ jamur $C$. militaris $+100 \mathrm{ml}$ air/polybag. Lama waktu infeksi disebabkan oleh beberapa faktor yaitu cara pengaplikasian, konsentrasi spora, saat aplikasi dan kondisi lingkungan. Hal ini sesuai dengan Prayogo (2006) yang menyatakan faktor-faktor yang mempengaruhi keefektifan jamur C. millitaris antara lain asal isolat, kerapatan konidia, kualitas media tumbuh, jenis hama yang dikendalikan, waktu aplikasi, frekuensi aplikasi dan faktor lingkungan. 
Setelah terinfeksi maka pupa akan mengalami kematian. Persentase pupa yang mati terinfeksi ditampilkan pada tabel 2. Tabel 2 menunjukkan bahwa pada pengamatan hari ke6 perlakuan P2, P3, dan P4 tidak berbeda nyata, tetapi berbeda nyata dengan perlakuan P1 dan P0. Pada pengamatan hari ke-12 perlakuan P1, P2, P3 dan P4 tidak berbeda nyata tetapi berbeda nyata dengan P0. Pupa yang mati terinfeksi tercepat terjadi pada perlakuan P4 dan diikuti oleh perlakuan P3 yang membutuhkan waktu hanya 12 hari. Perlakuan yang lain membutuhkan waktu lebih dari 12 hari pengamatan.

Pada hari ke-6 aplikasi jamur $C$. militaris dengan dosis $40 \mathrm{~g}+100 \mathrm{ml}$ air/polybag dapat menginfeksi dan mematikan pupa $S$. asigna dengan baik yaitu dengan kematian hampir $40 \%$. Pada hari ke-12 tingkat kematian pupa meningkat sampai $100 \%$, karena sudah memiliki konsentrasi spora yang cukup untuk menginfeksi seluruh pupa pada hari ke-12.

Tabel 2. Persentase pupa terinfeksi yang mati (\%)

\begin{tabular}{ccccc}
\hline \multirow{4}{*}{ Perlakuan } & \multicolumn{4}{c}{ Waktu pengamatan (hari setelah aplikasi) } \\
\cline { 2 - 5 } & 3 & 6 & 9 & 12 \\
\hline P0 & $0,00 \mathrm{c}$ & $0,00 \mathrm{c}$ & $0,00 \mathrm{c}$ & $0,00 \mathrm{c}$ \\
P1 & $0,00 \mathrm{c}$ & $15,55 \mathrm{bc}$ & $35,55 \mathrm{ab}$ & $62,22 \mathrm{a}$ \\
P2 & $0,00 \mathrm{c}$ & $20,00 \mathrm{ab}$ & $46,66 \mathrm{a}$ & $68,89 \mathrm{a}$ \\
P3 & 0,00c & $24,44 \mathrm{ab}$ & $57,78 \mathrm{a}$ & $86,66 \mathrm{a}$ \\
P4 & 0,00c & $37,08 \mathrm{ab}$ & $68,89 \mathrm{a}$ & $100,00 \mathrm{a}$ \\
\hline Keterangan : Angka yang diikuti huruf yang sama tidak \\
\multicolumn{5}{c}{ berbeda nyata menurut uji jarak Duncan } \\
\multicolumn{5}{c}{ pada taraf 5\%. }
\end{tabular}

\section{KESIMPULAN}

Media untuk memperbanyak jamur entomopatogen $C$. militaris yang terbaik adalah media dedak. Jamur $C$. militaris efektif untuk mengendalikan ulat api ( $S$. asigna) pada fase pupa. Dosis jamur entomopatogen $C$. militaris pada media dedak $40 \mathrm{~g}+100 \mathrm{ml}$ air/polibag efektif untuk mengendalikan ulat api pada fase pupa.

Disarankan untuk penelitian selanjutnya adalah membandingkan jumlah spora/ml dan viabilitasnya yang efektif untuk pengendalian ulat api ( $S$. asigna) fase pupa. 


\section{DAFTAR PUSTAKA}

Backer, R., Rokem, J. S., llangumaran, G., Lamont, J., Praslickova, D., Ricci, E., Subramanian, S., \& Smith, D. L. (2018). Plant growth-promoting rhizobacteria: Context, mechanisms of action, and roadmap to commercialization of biostimulants for sustainable agriculture. Frontiers in Plant Science, 871(October), 1-17. https://doi.org/10.3389/fpls.2018.01473

Cha-um, S., Yamada, N., Takabe, T., \& Kirdmanee, C. (2013). Physiological features and growth characters of oil palm (Elaeis guineensis jacq.) in response to reduced waterdeficit and rewatering. Australian Journal of Crop Science, 7(3), 432-439.

Ferreira, P., Abuna, G., Menezes, A., Sinhoreti, M., Carvalho, C., Consani, S., \& Bauer, J. (2016). Experimental $\mathrm{ZnO}$ cement containing bioactive niobium biophosphate fillers. Dental Materials, 32, e69. https://doi.org/10.1016/j.dental.2016.08.144

Zhu, Y., Wang, Z., Wang, J., Wang, Z., \& Zhou, J. (2014). Plant growth-promoting rhizobacteria improve shoot morphology and photosynthesis in dryland spring wheat. WIT Transactions on the Built Environment, 145(December), 343-350. https://doi.org/10.2495/ICBEEE20130431 